\title{
CHARACTERISTICS OF THE BAT (CHIROPTERA) POPULATION IN PROTECTED AREAS IN THE NORTHERN AND MIDDLE TAIGA SUBZONES OF EUROPEAN RUSSIA
}

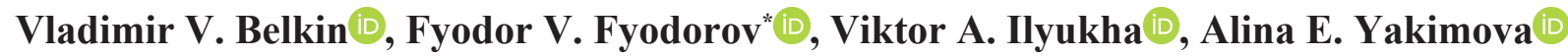 \\ Institute of Biology of Karelian Research Centre of RAS, Russia \\ *e-mail:ffyodoroff@inbox.ru
}

Received: 16.04.2020. Revised: 12.10 .2020 . Accepted: 22.10.2020.

\begin{abstract}
The overall bat (Chiroptera) fauna of Protected Areas in the forest zone of European Russia has not yet been assessed, although papers on some Protected Areas are being published quite regularly. Along its north-to-south gradient, this extensive area spans a great variety of habitats suitable for bat populations with vastly diverse compositions. In our review of bat species, we focused on eight Protected Areas in the northern and middle taiga, as well as on a comparative summary of the faunal data for the forest zone of European Russia in general. Surveys using a bat detector and by mist-netting resulted in identification of the species composition, relative abundance, relative density and spatial distribution of bats in Protected Areas. The following nine bat species were recorded: Myotis nattereri, M. mystacinus, M. brandtii, M. daubentonii, M. dasycneme, Plecotus auritus, Nyctalus noctula, Eptesicus nilssonii, Vespertilio murinus. We regularly recorded ultrasonic signals from Plecotus auritus, Nyctalus noctula and Vespertilio murinus up to $66^{\circ} \mathrm{N}$, which is much farther north that the species ranges indicated on IUCN maps. This result came as a surprise, considering there had been no specialised censuses in the Republic of Karelia or the Arkhangelsk region for decades. In Protected Areas, bat communities were dominated by Eptesicus nilssonii, which is specific to the northern taiga and middle taiga subzones. We discuss some ecological preferences of this species, such as a relatively higher tolerance of $E$. nilssonii towards temperature, but not towards air humidity in winter roosts, which may help it to thrive at high latitudes. At the same time, E. nilssonii is either missing from more southern parts of the forest zone or its relative abundance there is lower, while the dominant faunal elements are Myotis daubentonii (Darwin State Nature Reserve), Nyctalus noctula (Smolenskoye Poozerye National Park, Oksky State Nature Reserve, Bryansky Les State Nature Reserve) and Pipistrellus nathusii (Prioksko-Terrasny State Nature Reserve). Additionally, bat captures by using mist nets in the Vodlozersky National Park revealed the northernmost records of Myotis mystacinus in European Russia $\left(62.224867^{\circ} \mathrm{N}, 37.081629^{\circ} \mathrm{E}\right.$ and $\left.62.466342^{\circ} \mathrm{N}, 36.673240^{\circ} \mathrm{E}\right)$. Finally, we argue that recent bat records demand a revision of the status of bats in regional Red Data Books.
\end{abstract}

Key words: distribution, Red Data Book, relative abundance, relative density, species composition

\section{Introduction}

In contrast to the majority of West European countries, European Russia spans a wide spectrum of vegetation zones from north to south, the forest zone being the most extensive one. All of this area, from the northern taiga in the Kola Peninsula to nemoral forests of Central Russia, is highly attractive for bats (Strelkov \& Ilyin, 1990). The latitudinal sequence of vegetation zones offers a variety of quite specific habitats for bats. Owing to the availability of shelter, foraging and breeding environments these territories can be utilised by both migratory and sedentary bat species. There is zonation in the microclimates of underground shelters and their usability for individual bat species in relation to the different energy costs of hibernation (Anufriev, 2008). The bat species diversity is known to be closely correlated with latitude, climatic features, duration of seasons (Ulrich et al., 2007; Michaelsen et al., 2011), altitudinal and temperature gradients (Michaelsen, 2016). The European bat fauna gets poorer from the south to the north of the continent, so that eventually only the northern bats live and breed above the Arctic Circle (Rydell et al., 1994). It enjoys some advantages over other species, including physiologicalbiochemical parameters, high resistance to negative temperatures, and a high ecological valence at hibernacula (Belkin et al., 2019a).

Climate change and urbanisation are the two leading processes that can drive the range expansion of bats (Hamphries et al., 2002; Strelkov, 2004; Rebelo et al., 2010; Ancillotto et al., 2016) and insects, i.e. their potential prey (Shutova, 2016), in the forest zone, too. A wide application of acoustic observations in ecological and biogeographic studies, in particular at the northern limits of species ranges (Ahlén et al., 2007, 2009; Jones et al., 2013; Poerink et al., 2013; Rydell et al., 2014, 2020; Michaelsen, 2016; Belkin et al., 
2018, 2019b; Tidenberg et al., 2019), helps quickly detect the dynamical processes in the species composition, abundance, migratory behaviour and distribution of certain bat species.

The key challenges in the study and conservation of chiropterans in Russia, including Protected Areas (PAs), have been articulated by a number of specialists (Snitko, 2000; Bolshakov et al., 2005; Vekhnik \& Sachkov, 2005). But many of them still remain to be addressed. Owing to the high interest in bats, observed foremost in PAs, chiropteran checklists have been compiled for many PAs, patterns of their stay and distribution across the areas were determined, the ecological characteristics of species were better studied, etc. However, previous fieldwork was mostly done in the summer seasons, when both sedentary and migratory bats can be encountered. The vast dataset from study years has been chiefly published in Russia. But for a variety of reasons, unfortunately, it did not represent the status reports of European chiropterans or papers on the biogeography of this group of animals on the continent (Mitchell-Jones et al., 1999; Pereswiet-Soltan, 2007; Dietz et al., 2011).

Russia's well-developed Protected Area network (in many of which bats have been studied) permits defining the aim of this paper, which concerns the investigation of spatial patterns in the characteristics of chiropteran communities in the forest zone of European Russia. The tasks include a brief analysis of the latitudinal changes of the species composition across the forest zone and first conclusions on the bat fauna in PAs of the least studied region, the northern and middle taiga subzones (Bogdarina \& Strelkov, 2003).

\section{Material and Methods}

The geographical patterns in the distribution of chiropteran communities in PAs in the forest zone (Fig. 1) were analysed based on recent literature and the results of our own fieldwork in the Republic of Karelia, Murmansk region and Arkhangelsk region in late July - August of 2016-2019. Fieldwork was carried out in state nature reserves (SNR), national parks (NP) and other Pas, namely natural parks, nature sanctuaries, and natural monuments. Their status is defined according to the Russian Federal Act on Protected Areas №33-FZ (dated by 14.03.1995). We conducted car surveys in summer using a static bat detector in eight PAs. The total length of car routes surveyed was $1040 \mathrm{~km}$, of which $600 \mathrm{~km}$ were in fifteen $40-\mathrm{km}$ transects. In the PAs with a poor road network, surveys were conducted on foot with sampling at fixed points, like bridges, shores and banks, forest glades, isolated buildings, and others. Water bodies in the PAs were surveyed along $120 \mathrm{~km}$ of transects from motor boats, i.e. nine water transects, $12 \mathrm{~km}$ to $20 \mathrm{~km}$ each depending on the size of the water body. Visual observations with identification were based on exterior traits and flight characteristics were used. Two dead bats collected during fieldwork were treated. Counts at fixed points lasted $278 \mathrm{~h}$.

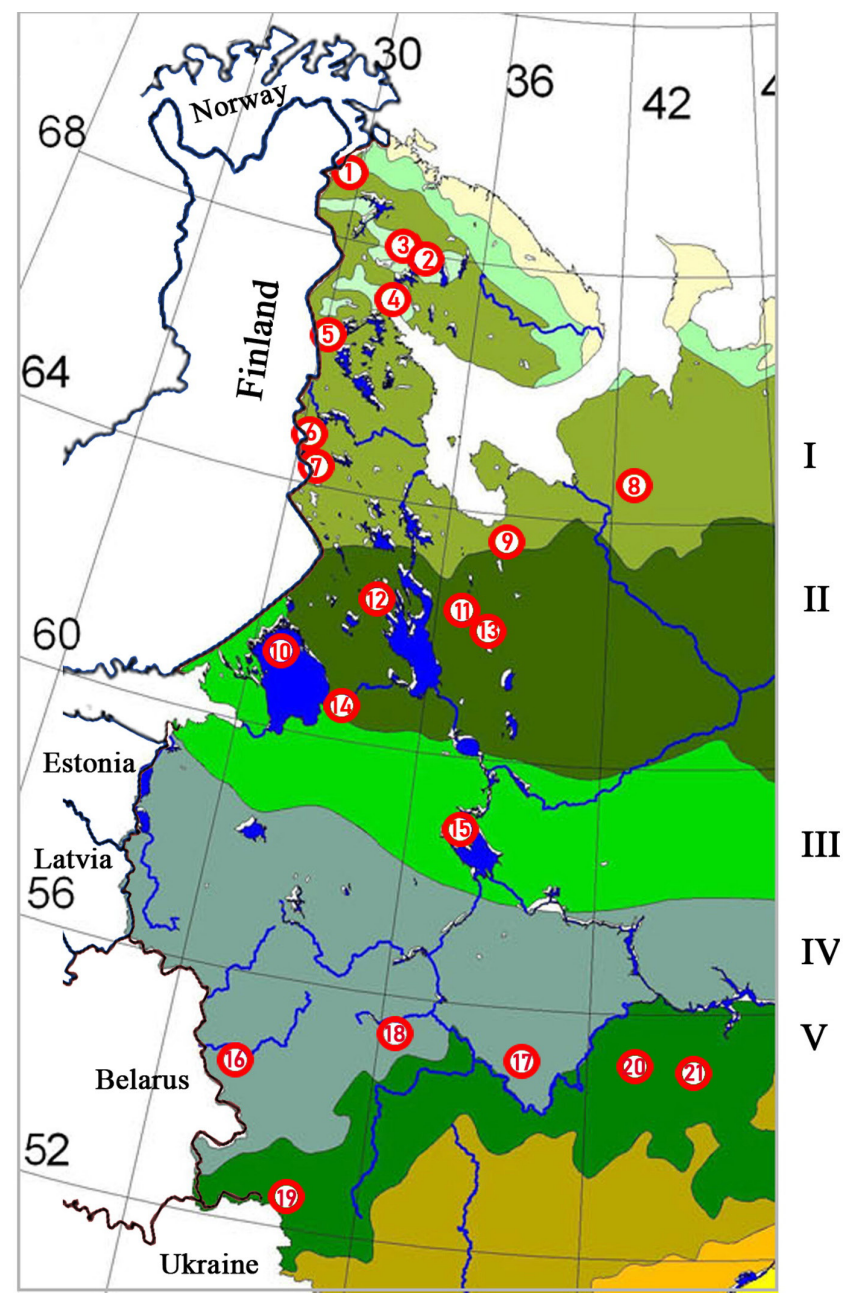

Fig. 1. Locations of the studied Protected Areas in the forest zone of European Russia. Designations: I - northern taiga subzone (1 - Pasvik State Nature Reserve, 2 - Avrorin Polar-Alpine Botanical Garden Institute, 3 - Laplandsky State Nature Reserve, 4 - Kandalakshsky State Nature Reserve, 5 - Paanajarvi National Park, 6 - Kalevalsky National Park, 7 - Kostomuksha State Nature Reserve, 8 - Pinega State Nature Reserve, 9 - Kozhozersky Regional Landscape Reserve), II middle taiga subzone (10 - Valaam Archipelago Regional Nature Park, 11 - Vodlozersky National Park, 12 - Kivach State Nature Reserve, 13 - Kenozersky National Park, 14 - NizhneSvirsky State Nature Reserve), III - southern taiga subzone (15 - Darwin State Nature Reserve), IV - subzone of subboreal forests (16 - Smolenskoye Poozerye National Park, 17 - Oksky State Nature Reserve, 18 - Prioksko-Terrasny State Nature Reserve), V - subzone of nemoral forests (19 - Bryansky Les State Nature Reserve, 20 - Mordovia State Nature Reserve, 21 - Smolny National Park) (Map with modifications according to Zaugolnova \& Martynenko, 2014). 
Summer counts of bats covered an area from $61^{\circ} \mathrm{N}, 29^{\circ} \mathrm{E}$ to $66^{\circ} \mathrm{N}, 44^{\circ} \mathrm{E}$. The species diversity, distribution and relative abundance (\%) were determined along routes surveyed by car driven at around $40 \mathrm{~km} / \mathrm{h}$ throughout the night. Bat counts at fixed points were run in the automatic mode throughout night time, with the detector deployed $1 \mathrm{~h}$ before sunset and collected $2 \mathrm{~h}$ after sunrise. Each night a car route started with surveying a $40-\mathrm{km}$ transect and then continued until sunrise. Counts commenced $45 \mathrm{~min}$ after sunset (Russ et al., 2003; Jones et al., 2013) to enable determination of the relative density of bats (individuals per $1 \mathrm{~km}$ ) in $40-\mathrm{km}$ transects, in addition to the indices listed above. The counting surveys employed a static detector Song Meter SM2 Bat+ (USA) with omnidirectional external microphone installed on top of the car roof. Detector-facilitated bat counts at water bodies were carried out from motor boat driven at $10-15 \mathrm{~km} / \mathrm{h}$ along the shoreline at 20-30 m distance.

Species identification was done automatically by Kaleidoscope Pro software (ver. 3.1.1.). We used the classifier for Finland so that the software does not need to run through the entire European list of bat when processing the records. This, given the low bat diversity in our region, significantly improved the accuracy of species identification, which many specialists now believe to be insufficiently reliable and credible (Russo \& Voigt, 2016; Rydell et al., 2017). Myotis brandtii Eversmann, 1845 and $M$. mystacinus Kuhl, 1817 were not differentiated since the characteristics of the signals they emit were identical. The software allows identifying a species uniquely at a known confidence level using a series of three to several tens of signals. In faunal studies, this can be regarded as a positive sign, indicating the presence of a species in the area. Specification of the real time of recording for echo-location files makes it easier to spot individual bats along the route. The time interval between files was usually $1 \mathrm{~min}$ to $60 \mathrm{~min}$. Given the speed at which the car was moving $(10-11 \mathrm{~m} / \mathrm{s})$, all signals of one species received within less than $10 \mathrm{~s}$ were deemed to belong to one individual. This approach minimises the interference of a sole bat flying around the detector with the output (Miller, 2001).

In PAs, sampling was mostly performed by a non-contact method (ultrasound detection), with only one occasion of bat capturing by mist nets in combination with recording by a detector.
This approach is particularly relevant for PAs, and enables not only covering specific key sites in the PAs (Vekhnik \& Sachkov, 2005; Shpak, 2019), but also taking a census of bats throughout the available area at a minimum cost.

Netting of bats (with two $3 \times 6 \mathrm{~m}$ mist nets with $15 \mathrm{~mm}$ mesh size) was carried out in Vodlozersky NP during seven nights. The animal species, sex and time of capture were recorded, after which they were placed in a canvas bag to be released early in the morning. Myotis brandtii and Myotis mystacinus were determined morphologically (Hanák, 1970; Baagøe, 1973; Strelkov \& Buntova, 1982; Lehmann, 1983-1984) based on penis shape in males and cranial material (bat bagging permit №00015 from the Republic of Karelia Ministry of Natural Resources and the Environment). We also controlled four potential bat day-roosts. Pipistrellus records from PAs in sub-boreal and nemoral forests published before 1999 were re-identified using museum exhibits as Pipistrellus pygmaeus Leach, 1825 (Barlow \& Jones, 1999; Kruskop, 2007).

In addition to our summer surveys, in 20162019 we determined the species composition of wintering bats in the northern and middle taiga subzones, and the microclimate conditions in the hibernacula. A total of 13 mine galleries and five underground fortifications were surveyed (Fig. 2). The census was done by visually examining the whole space for bats. Microclimate characteristics in the sites occupied by hibernating bats in underground winter roosts were measured by a handheld Testo 410-2 vane anemometer with humidity and temperature sensors (Germany). The temperature radiated from surfaces inside the shelter and the body surface temperature of bats $(\mathrm{n}=90$ : nine individuals of M. mystacinus, 12 M. brandtii, 11 Myotis daubentonii Kuhl, 1817, ten Plecotus auritus Linnaeus, 1758, 48 Eptesicus nilssonii Keyserling $\&$ Blasius, 1839) were measured by Testo $875-1 \mathrm{i}$ thermal imager with Super Resolution option. The resultant electronic thermograms were treated with Testo IRSoft (ver. 4.0) software.

\section{Results and Discussion}

Analysis of the material in Table 1 reveals a regular increase in the bat species richness from north to south in the forest zone of European Russia. The same trend is observed also for the whole of Western Europe (Pereswiet-Soltan, 2007). Previously, only one to three species have been known from some PAs in the northern and middle taiga, where hardly any specialised bat 
censuses were carried out. For a majority of the PAs (Paanajarvi NP, Kalevalsky NP, Vodlozersky NP, Kenozersky NP, and Kostomukshsky SNR), data on bats were missing altogether. The main source of information from SNR and NP of the Murmansk region, Arkhangelsk region and the Republic of Karelia has been accidental encounters. Only the application of ultrasound detection has recently enabled the collection of mass-scope information on the bat species composition in some PAs in North European Russia. We recorded the presence of bats on 447 occasions representing 447 bats at minimum. There were Myotis nattereri Kuhl, 1817, M. brandtii/mystacinus, $M$. daubentonii, M. dasycneme Boie, 1825, Plecotus auritus, Nyctalus noctula Schreber, 1774, Eptesicus nilssonii, Vespertilio murinus Linnaeus, 1758. Besides, 26 bat individuals belonging to four species were captured (Myotis mystacinus, M. brandtii, M. daubentonii, Eptesicus nilssonii).

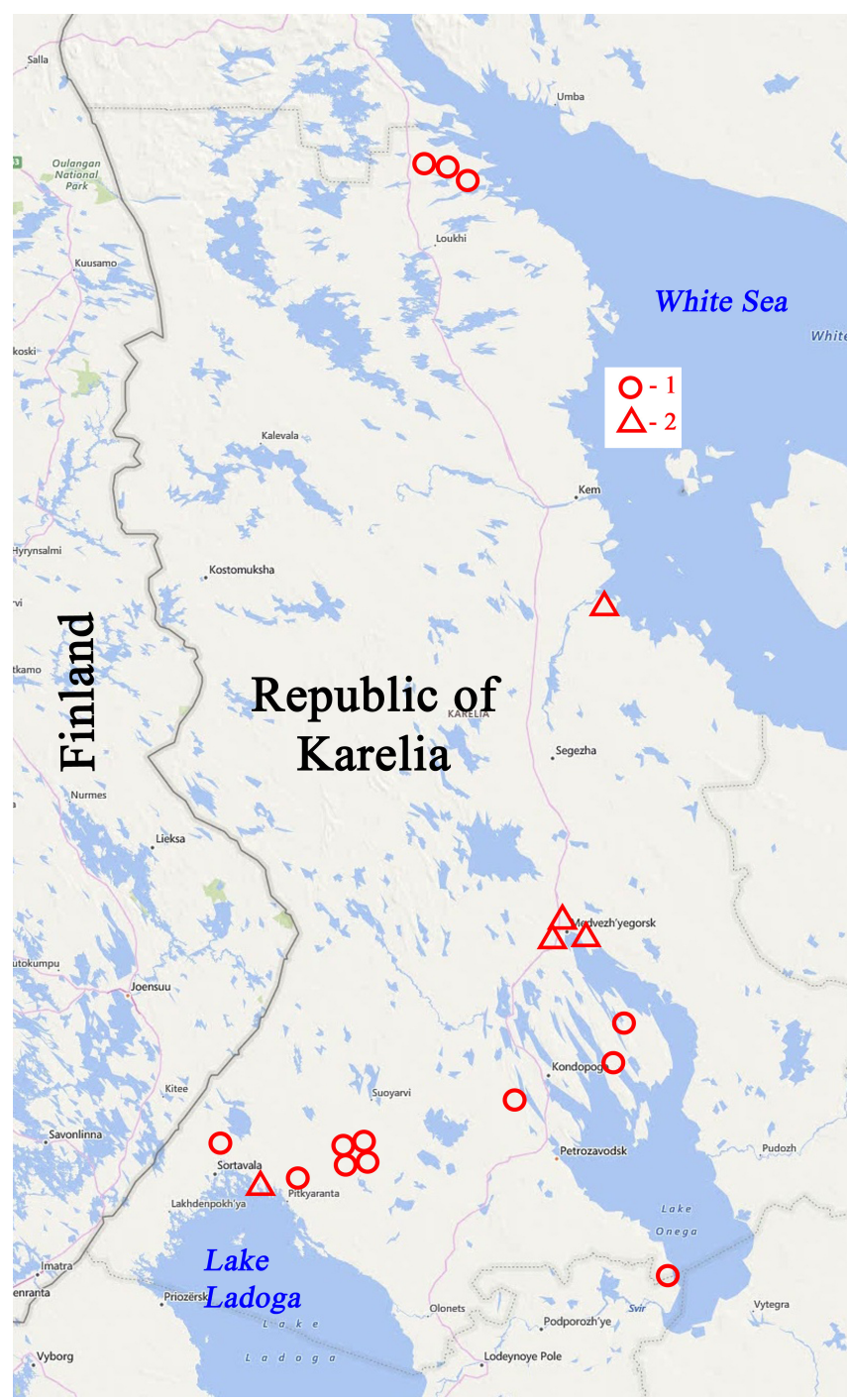

Fig. 2. Locations of underground hibernacula surveyed in the northern and middle taiga of the Republic of Karelia. Designations: 1 - mine galleries, 2 - fortifications.
Surveys in southern taiga forests, sub-boreal forests and nemoral forests in PAs yielded records of 8 to 12 species (Table 1). The main census method was mist-netting, which provides the most successful results. Importantly, this is a long-term effort, often arranged as monitoring.

The relative bat abundance in northern and middle taiga PAs features a dominance of $E p$ tesicus nilssonii (Table 2). This is their major difference from PAs in more southern parts of the forest zone (Table 3), which are noted for the absence or scantiness of E. nilssonii and Plecotus auritus, a high share of Nyctalus noctula and Pipistrellus nathusii Keyserling \& Blasius, 1839, and the presence of Nyctalus leisleri Kuhl, 1817 and Pipistrellus pygmaeus.

PAs above the Arctic Circle (Murmansk region) have yielded no records of species other than E. nilssonii for decades. Our several-dayslong ultrasound detection surveys in the PolarAlpine Botanical Garden Institute produced no encounters of this species either. There are no reports of its wintering in the Murmansk region. Consequently, at the northern limit of its distribution range, E. nilssonii is a Red Data Book species in the Murmansk Region (Boiko, 2014). The explanation is not only that the species encounters are not annually regular in the region, including its PAs (Pasvik SNR, Kandalakshsky SNR, Laplandsky SNR) (Semenov-Tjan-Shanskii, 1982; Boiko, 2014; Kataev, 2018), but also that there have been hardly any specialised bat censuses in the region and information about the species is clearly deficient. However, E. nilssonii may be subject to unexpected population changes. In Sweden (Rydell et al., 2020), decades-long monitoring of E. nilssonii on a $27-\mathrm{km}$ long road revealed a sharp decline in the local population of this species, wherefore it is assumed that its conservation status may have been changed.

Our ultrasound detection surveys in the Paanajarvi NP were carried out late July 2018, and yielded records of four species (Plecotus auritus, Nyctalus noctula, Eptesicus nilssonii and Vespertilio murinus). They were encountered both in forest sites along the road running from the south to the north of the PA, and along the River Olanga in forest and farmland habitats. Paanajarvi NP and its northern surroundings $\left(66.343243^{\circ} \mathrm{N}, 30.343737^{\circ} \mathrm{E}\right)$ are the northernmost points where $P$. auritus, $N$. noctula, and $V$. murinus have been recorded in the Northern Europe. This is much farther north than the 
species ranges indicated in IUCN maps (www. iucnredlist.org). Interestingly, previous studies using a stable isotope approach predicted the origins of some $N$. noctula populations to be farther north than the current species range according to IUCN (Lehnert et al., 2014; Voigt et al., 2016).
The only species recorded at Lake Paanajarvi itself was $N$. noctula. The Paanajarvi NP may also harbour Myotis daubentonii reported by Finnish researchers (Siivonen \& Wermundsen, 2008) from the mouth of the River Oulankajoki into Lake Paanajarvi in Finland.

Table 1. Summer bat populations in Protected Areas (PAs) in the forest zone of European Russia

\begin{tabular}{|c|c|c|c|c|}
\hline PA, region, № in Fig. 1 & PA size, $\mathrm{km}^{2}$ & Species composition* & $\begin{array}{c}\text { Survey } \\
\text { method** }\end{array}$ & Source \\
\hline \multicolumn{5}{|c|}{ Northern taiga } \\
\hline Pasvik SNR, Murmansk region, №1 & 147.27 & En & 1 & Kataev, 2018 \\
\hline Botanical Garden Institute, Murmansk region, №2 & 16.70 & - & 3 & our data \\
\hline Laplandsky SNR, Murmansk region, №3 & 2784.36 & En & 1 & Semenov-Tjan-Shanskii, 1982 \\
\hline Kandalakshsky SNR, Murmansk region, №4 & 705.00 & En & 1 & Boiko, 2014 \\
\hline Paanajarvi NP, Republic of Karelia, №5 & 1043.54 & Pla, Nn, En, Vm & 3 & our data \\
\hline Kalevalsky NP, Republic of Karelia, №6 & 744.00 & Mdas, Pla, Nn, En & 1,3 & our data \\
\hline Kostomuksha SNR, Republic of Karelia, №7 & 492.59 & $\mathrm{Mdb}, \mathrm{Pla}, \mathrm{Nn}, \mathrm{En}, \mathrm{Vm}$ & 1,3 & our data \\
\hline Pinega SNR, Arkhangelsk region, №8 & 518.90 & Mbr, En, Vm & 1,3 & our data; Rykov, 2008a \\
\hline \begin{tabular}{|l|} 
Kozhozersky Landscape Sanctuary, Arkhangelsk region, №9 \\
\end{tabular} & 2016.05 & En & 1 & Mamontov, 2006 \\
\hline \multicolumn{5}{|c|}{ Middle taiga } \\
\hline Valaam Archipelago Nature Park, Republic of Karelia, №10 & 247.00 & Mbr, Mdb, Pla, Nn, En, Vm & $1,2,3$ & our data; Bogdarina, 2004 \\
\hline Vodlozersky NP, Republic of Karelia, №11 & 1306.00 & Mn, Mbr, Mdb, Mdas, Pla, Nn, En, Vm & $1,2,3$ & our data \\
\hline Kivach SNR, Republic of Karelia, №12 & 108.70 & Mm, Pla, En & 1 & our data; Zimin \& Ivanter, 1969 \\
\hline Kenozersky NP, Arkhangelsk region, №13 & 1402.18 & Mdb, Mdas, Pla, Nn, En & 1,3 & our data \\
\hline Nizhne-Svirsky SNR, Leningrad region, №14 & 423.90 & Mdb, Pla, En, Vm & 1 & Starikov \& Popov, 2012 \\
\hline \multicolumn{5}{|c|}{ Southern taiga } \\
\hline Darwin SNR, Vologda region and Yaroslavl regions, №15 & 1127.00 & Mbr, Mdb, Mdas, Nl, Nn, Pn, En, Vm & 2 & Vasenkov \& Sidorchuk, 2010 \\
\hline \multicolumn{5}{|c|}{ Sub-boreal forests } \\
\hline Smolenskoye Poozerye NP, Smolensk region. №16 & 1462.37 & $\begin{array}{l}\text { Mm, Mbr, Mdb, Pla, Nl, Nn, Ppyg, } \\
\text { Pn, En, Vm }\end{array}$ & 2 & Vasenkov et al., 2017 \\
\hline Oksky SNR, Ryazan region, №17 & 560.27 & $\begin{array}{l}\text { Mm, Mbr, Mdb, Mdas, Pla, Nl, Nn, } \\
\text { Ppyg, Pn, En, Vm }\end{array}$ & 2 & Vlaschenko et al., 2016 \\
\hline Prioksko-Terrasny SNR, Moscow region, №18 & 49.45 & $\begin{array}{l}\text { Mn, Mbr, Mdb, Mdas, Pla, Nl, Nn, } \\
\text { Ppyg, Pn, Vm }\end{array}$ & $1,2,3$ & Albov et al., 2009 \\
\hline \multicolumn{5}{|c|}{ Nemoral forests } \\
\hline Bryansky Les SNR, Bryansk region, №19 & 121.86 & $\begin{array}{l}\text { Mbr, Mdb, Pla, Nl, Nn, Nlas, Ppyg, } \\
\text { Pn, Pk, En, Es, Vm }\end{array}$ & $1,2,3$ & $\begin{array}{l}\text { Vlaschenko et al., 2016; Sitnikova } \\
\text { et al., 2009; Shpilenok et al., } 1997\end{array}$ \\
\hline Mordovia SNR, Republic of Mordovia, №20 & 321.62 & $\begin{array}{l}\text { Mn, Mbr, Mdb, Mdas, Pla, Nn, Ppyg, } \\
\text { Pn, Pk }\end{array}$ & $1,2,3$ & Artaev \& Smirnov, 2016 \\
\hline Smolny NP, Republic of Mordovia, №21 & 365.00 & Mbr, Mdb, Mdas, Pla, Nn, Ppyg, Pn, Pk & $1,2,3$ & Artaev \& Smirnov, 2016 \\
\hline
\end{tabular}

Note: * Designations: Mn - Myotis nattereri, Mm - M. mystacinus, Mbr - M. brandtii, Mdb - M. daubentonii, Mdas - M. dasycneme, Pla - Plecotus auritus, $\mathrm{N} 1$ - Nyctalus leisleri, Nn - N. noctula, Nlas - N. lasiopterus Kuhl, 1817, Ppyg - Pipistrellus pygmaeus, Pn - P. nathusii, Pk - P. kuhlii Kuhl, 1817, En - Eptesicus nilssonii, Es - E. serotinus Schreber, 1774, Vm - Vespertilio murinus; ** Survey method: 1 - visual observations and sampling of biological material, 2 - mist-netting, 3 - ultrasound detection.

Table 2. Relative abundance (\%) of bats in PAs in the northern and middle taiga subzone of European Russia (our data, ultrasound detection)

\begin{tabular}{|c|c|c|c|c|c|}
\hline Species & 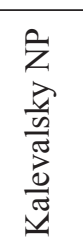 & 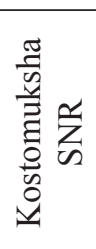 & 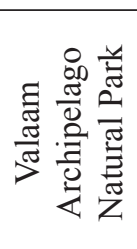 & $\begin{array}{l}\text { Z } \\
\text { 离 } \\
\text { 岕 } \\
\text { N } \\
\frac{0}{0} \\
\stackrel{0}{\circ}\end{array}$ & 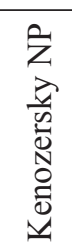 \\
\hline Myotis nattereri & - & - & - & 1.3 & - \\
\hline Myotis brandtii/mystacinus & - & - & - & 5.1 & - \\
\hline Myotis daubentonii & - & 5.3 & 1.0 & 9.0 & 12.0 \\
\hline Myotis dasycneme & 2.6 & & 2.0 & 11.5 & 4.0 \\
\hline Plecotus auritus & 2.6 & 5.3 & 5.9 & 24.4 & 12.0 \\
\hline Nyctalus noctula & 46.1 & 5.3 & 44.1 & 9.0 & 16.0 \\
\hline Eptesicus nilssonii & 48.7 & 73.6 & 41.4 & 33.3 & 56.0 \\
\hline Vespertilio murinus & - & 10.5 & 5.9 & 6.4 & - \\
\hline
\end{tabular}


Table 3. Relative abundance (\%) of bats in PAs in the southern taiga subzone, sub-boreal forests and nemoral forests of European Russia (according to Albov et al., 2009; Vasenkov \& Sidorchuk, 2010; Vlaschenko et al., 2016; Vasenkov et al., 2017; method: mist-netting)

\begin{tabular}{|c|c|c|c|c|c|}
\hline Species & 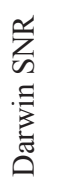 & 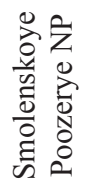 & $\begin{array}{l}a \\
z \\
\sim \\
\frac{z}{n} \\
\frac{n}{0}\end{array}$ & 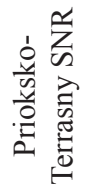 & 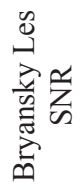 \\
\hline Myotis nattereri & - & - & - & 3.5 & - \\
\hline Myotis mystacinus & - & 0.2 & 0.3 & - & - \\
\hline Myotis brandtii & 1.1 & 0.8 & 7.3 & 13.2 & 12.2 \\
\hline Myotis daubentonii & 37.8 & 2.3 & 17.0 & 14.0 & 3.9 \\
\hline Myotis dasycneme & 14.6 & - & 6.2 & 9.6 & - \\
\hline Plecotus auritus & - & 0.8 & 4.1 & 0.9 & 1.9 \\
\hline Nyctalus leisleri & - & 2.3 & 4.1 & 1.8 & 1.9 \\
\hline Nyctalus noctula & 13.6 & 38.7 & 35.8 & 5.3 & 41.2 \\
\hline Pipistrellus pygmaeus & - & 1.2 & 2.9 & 6.1 & 6.5 \\
\hline Pipistrellus nathusii & 19.4 & 22.6 & 17.3 & 43.8 & 21.9 \\
\hline Eptesicus nilssonii & 2.4 & 0.4 & - & - & - \\
\hline Vespertilio murinus & 11.2 & 30.7 & 5.0 & 1.8 & 10.3 \\
\hline
\end{tabular}

According to Strelkov (1997a,b), the limit of the breeding range in Northwest Russia lies at $60^{\circ} \mathrm{N}$ for Nyctalus noctula, and even slightly farther north for Vespertilio murinus. We speculate that the distribution range of these migratory species might extend even farther north owing to barren and immature animals, as corroborated by the results of our acoustic surveys in the middle and even northern taiga subzones, as well as by data from the latest Atlas of Finnish Bats (Tidenberg et al., 2019).

Presumably, the range expansion of migratory bat species has, in part, been promoted by the change of some climate parameters in the region. For instance, in the Kivach SNR $\left(62.276513^{\circ} \mathrm{N}, 33.981624^{\circ} \mathrm{E}\right)$, the change since 1970 has been a $1.4^{\circ} \mathrm{C}$ rise in average of the annual air temperature, a 23-day increase in climatic summer duration, and 52 more frost-free days on soil surface (Skorokhodova \& Shcherbakov, 2011). Such changes might alter the seasonal bat migrations along the latitudinal gradient.

In 2019, our surveys in the Kalevalsky NP produced records of four species (Myotis dasycneme, Plecotus auritus, Nyctalus noctula, and Eptesicus nilssonii). A major part of the Kalevalsky NP could not be surveyed because of the near absence of drivable roads. Therefore, only the eastern part of the PA was studied. In the censuses, Eptesicus nilssonii dominated (48.7\%), and it was recorded from Sudnozero, an only inhabited village in the Kalevalsky NP. It was on the shore of the lake bearing the same name, along the road from Sudnozero village to Pongaguba village. Two E. nilssonii individuals were sighted on a forest lakelet $70 \mathrm{~m}$ in diameter. Plecotus auritus records come from the road to the Sudnozero village, and from the immediate vicinities of the Kalevalsky NP, to the south, north and east of the PA. The relative abundance of this species was 2.6\%. Nyctalus noctula was noted in the Kalevalsky NP on the River Sudno, on Lake Sudnozero, and along the road to the village Sudnozero. The sequences of signals implying unique species identification were 17-297 pulses. It was twice sighted over the water, along the shoreline. In contrary to our expectations, the species' relative abundance was very high (46.1\%). Myotis dasycneme was recorded on Lake Sudnozero. In the nearest vicinity of the Kalevalsky NP, the species occurred along the shoreline of some nameless lakes to the south and east of the border of this PA. Its relative abundance was 2.6\%. Myotis dasycneme records from the Kalevalsky NP and its surroundings represent the northernmost locations detected for the species $\left(65.029154^{\circ} \mathrm{N}\right.$, $30.364445^{\circ} \mathrm{E}$ ) by ultrasound detection monitoring of bats in North European Russia.

In the Kostomuksha SNR (Fig. 3), our surveys in 2018 revealed five bat species (Myotis daubentonii, Plecotus auritus, Nyctalus noctula, Eptesicus nilssonii, and Vespertilio murinus). We also detected $P$. auritus and $V$. murinus in the buildings of the Kostomuksha SNR's Visitor Centre $\left(0.17 \mathrm{~km}^{2}\right.$ of forest with a lake and a small river) in the Kostomuksha settlement. Eptesicus nilssonii dominates in the Kostomuksha SNR in terms of relative abundance $(73.6 \%)$. This was the only species recorded in two $40-\mathrm{km}$ transects. Its relative density was 0.075 individuals per $1 \mathrm{~km}$ of transect. Nyctalus noctula was encountered along the water transect on Lake Minozero, Myotis daubentonii at a fixed point on the River Kamennaya, and $V$. murinus on a forest lakelet near Lake Kalevi. 


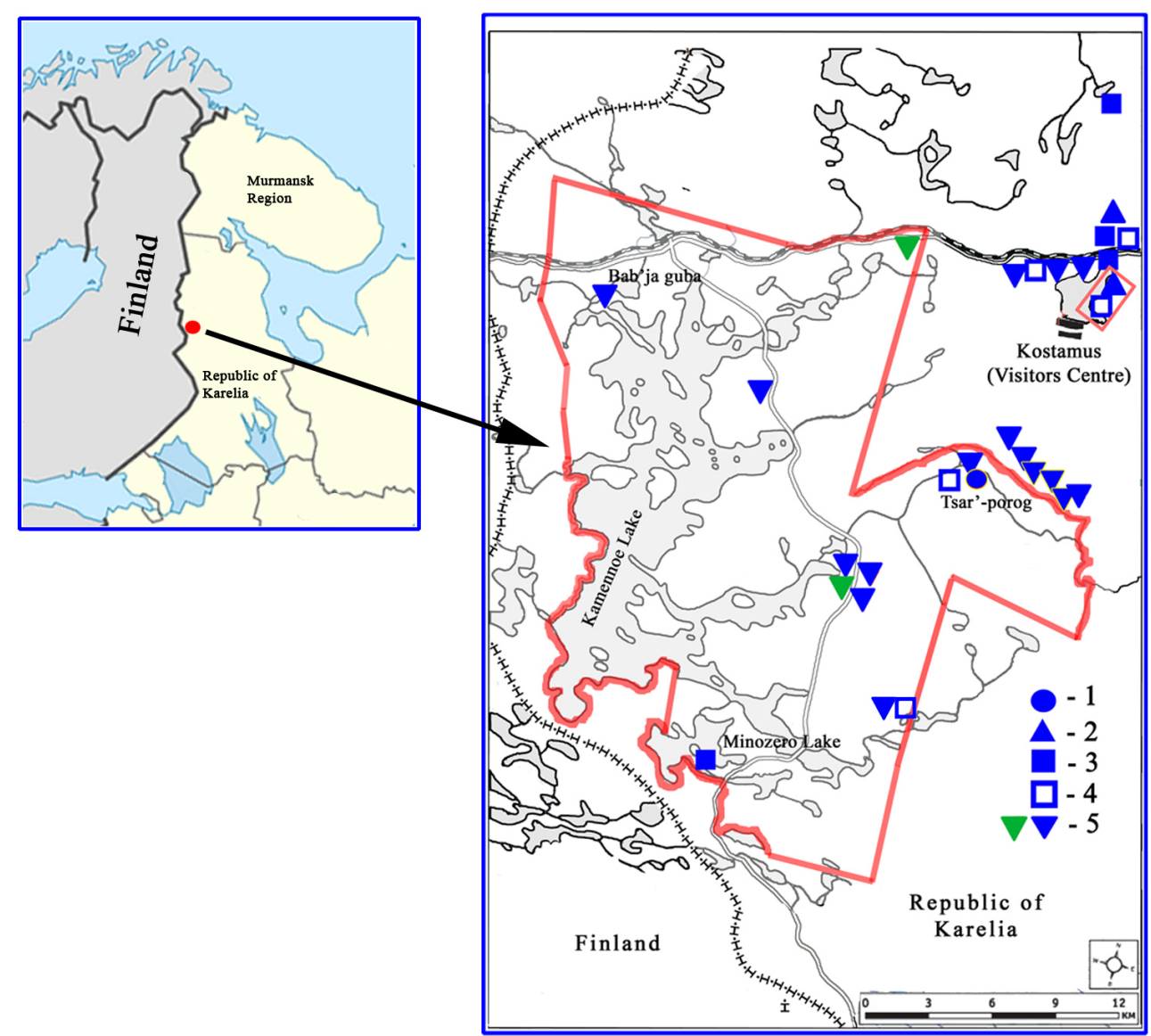

Fig. 3. Locations of bat records in the Kostomuksha State Nature Reserve. Designations: 1 - Myotis daubentonii, 2 - Plecotus auritus, 3 - Nyctalus noctula, 4 -Vespertilio murinus, 5 -Eptesicus nilssonii (green symbol - visual observations, blue symbols - ultrasound detections).

The results of censuses in the Metsola Biosphere Reserve (BR), which has an international status and incorporates areas of the Kalevalsky NP, Kostomuksha SNR and the Kostomuksha municipality, are given collectively for its component parts. In the Metsola BR, the bat species composition includes seven species (Myotis nattereri, M. daubentonii, $M$. dasycneme, Plecotus auritus, Nyctalus noctula, Eptesicus nilssonii, Vespertilio murinus), of which four (excluding $M$. daubentonii and $M$. dasycneme) were recorded in the Kostomuksha settlement and its green belt. Here, like in the Kalevalsky $\mathrm{NP}$, the sequences of pulses uniquely identified as belonging to $N$. noctula were unusually long (23-346 pulses). Records from water transects and fixed points include Lake Lamasjarvi $(P$. auritus, E. nilssonii, V. murinus), Lake Sudnozero (M. dasycneme, N. noctula, E. nilssonii), Lake Kamennoye (E. nilssonii), Lake Minozero (N. noctula), Lake Koriangi ( $N$. noctula), forest lakelets (M. dasycneme, P. auritus, N. noctula, E. nilssonii), River Kamennaya (M. daubentonii, E. nilssonii, $V$. murinus), River Sudno (N. noctula), River Tollojoki (M. daubentonii), River Kyure- lya (M. dasycneme, $N$. noctula), River Selvana ( $M$. nattereri, $M$. daubentonii, $M$. dasycneme, $N$. noctula), River Livo (P. auritus), and River Zhiga ( $N$. noctula).

The above mentioned species, except perhaps for $M$. nattereri and $M$. dasycneme, are widespread in the Metsola BR, and occur both in forest habitats and in water bodies. Recording of M. nattereri from an area reaching beyond PAs is quite explicable. Similar results have been reported before for other PAs (Mordovia SNR and Smolny NP) and the administrative units in which they are situated in the nemoral forest zone (Artaev \& Smirnov, 2016). The total relative density of chiropterans in the Metsola BR based on surveys of seven $40-\mathrm{km}$ transects was 0.289 individuals per km, including $M$. dasycneme with 0.007 individuals per $\mathrm{km}, P$. auritus with 0.021 individuals per $\mathrm{km}, N$. noctula with 0.143 individuals per $\mathrm{km}$, E. nilssonii with 0.100 individuals per $\mathrm{km}$, and $V$. murinus with 0.018 individuals per $\mathrm{km}$.

Summer car surveys with ultrasound detection along Pinega SNR outer borders in 2017, along a $40-\mathrm{km}$ transect from the village Pinega to the southern end of the Pinega SNR, detected 
18 E. nilssonii individuals and two V. murinus individuals. Vespertilio murinus was spotted on a lakelet where the road from Krasnaya Gorka forks to Maletino and to the village Pershkovo. Eptesicus nilssonii records come from the village Pinega, lakelets outside of this village, Krasnaya Gorka - Maletino road fork, Pekhorovsky creek, rivers Karjela and Belaya, as well as other points along the road to the southern end of the SNR. The relative density of E. nilssonii was 0.450 individuals per $\mathrm{km}$ of transect, the one of $V . m u$ rinus ( 0.050 individuals per $\mathrm{km})$, and is in total 0.500 individuals per $\mathrm{km}$ transect. Chiropteran censuses in karst caves near the Pinega SNR revealed the overwintering of two bat species $(M$. brandtii and E. nilssonii) (Rykov, 2008a,b). Eptesicus nilssonii predominated there. It is quite safe to say that all these species are present inside the Pinega SNR, too.

Chiropteran censuses in the Valaam Archipelago Natural Park (Lake Ladoga) in 2016 demonstrated the highest relative abundance for $N$. noctula, which could be expected, given the suitable climate and environmental conditions (Kravchenko \& Lazareva, 1989; Verzilin et al., 1990). There being few roads and plenty of important sights of interest, surveys were done both by car and on foot, taking stops at fixed points.
Bat records on Valaam Island are schematically mapped in Fig. 4.

Records from separate study sites of Valaam Island included: Valaam Archipelago Natural Park's office area (Plecotus auritus, Nyctalus noctula, Eptesicus nilssonii, Vespertilio murinus), winter hotel, orchard ( $N$. noctula, $E$. nilssonii), Preobrazhenskiy Cathedral (E. nilsso$n i i, V$. murinus), outskirts of fields behind the cathedral (N. noctula, E. nilssonii), monastery bay (P. auritus, $N$. noctula, E. nilssonii), larch alley, Hegumen's cemetery (N. noctula, E. nilssonii, $V$. murinus), helicopter landing site, farmland $(N$. noctula), Kukinsky Bay (bridge) (N. noctula), Tikhvinsky bridge (N. noctula, E. nilssonii), Lake Leshchyovoye (N. noctula, E. nilssonii), Old quay (Lake Ladoga) (E. nilssonii), 20-yearold pine forest (P. auritus, $N$. noctula), Vladimirsky bridge (Myotis daubentonii, M. dasycneme, E. nilssonii), White skete (E. nilssonii), first bridge to the skete of St. Nicholas (M. dasycneme, N. noctula, E. nilssonii), second and third bridges (E. nilssonii, V. murinus), chapel along the road to Kazansky skete (P. auritus, $N$. noctula, E. nilssonii), Kazansky skete (N. noctula, E. nilssonii). Previously, Bogdarina (2004) captured M. daubentonii, P. auritus and E. nilssonii in mist nets (Fig. 4, red symbols).

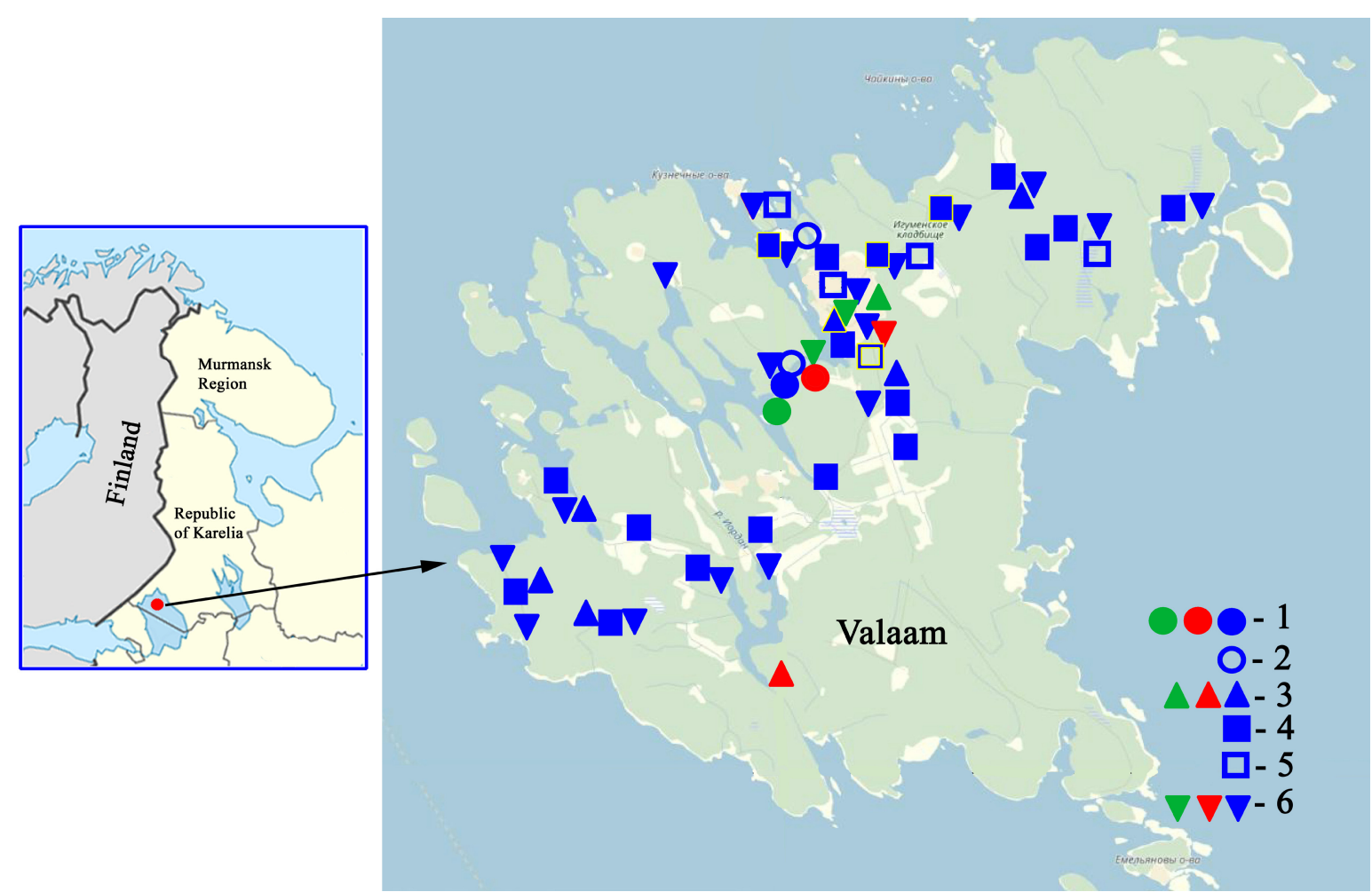

Fig. 4. Bat records in Valaam Archipelago Natural Park. Designations: 1 - Myotis daubentonii, 2 - Myotis dasycneme, 3 Plecotus auritus, 4 - Nyctalus noctula, 5 - Vespertilio murinus, 6 - Eptesicus nilssonii (green symbols - visual observations and sampling of biomaterial, red - mist-netting, blue - ultrasound detections). 
No specialised bat surveys have been carried out in the Kivach SNR. Plecotus auritus and E. nilssonii were encountered in its area in the midXX century (Zimin \& Ivanter, 1969). There had been no further accessions to this short list for many years until a recent finding of Myotis mystacinus (two dead animals in Kivach village). It is also worth mentioning that $M$. mystacinus, $M$. brandtii, M. daubentonii, and E. nilssonii have been encountered in different years during winter surveys in mine galleries in Pertnavolok (9 $\mathrm{km}$ from the southern border of the Protected Area). One can expect all these species to occur inside the Kivach SNR, too.

In 2019, Vodlozersky NP was surveyed using mist-netting (Pilmasozero, Sukhaya Vodla, Okhta, Vama, Kukshezero and Navdruchey), as well as by ultrasound detection at fixed points and along car transects (Table 4, Fig. 5). Additionally, two Myotis brandtii were captured at daytime roosts in an abandoned old house at Pilmasozero post and two more unidentified bats were sighted in the firewood shed at the Sukhaya Vodla post.

Ultrasound detection at fixed points revealed a wider bat species composition than mist-netting. We also found a high relative abundance of Myotis daubentonii and M. dasycneme, occurring on the water bodies which shores were surveyed.

In Vodlozersky NP, this combination of methods produced data on the dominance or high relative abundance of Eptesicus nilssonii (Table 4), but it was less pronounced than in the middle taiga subzone on average (Belkin et al., 2018). Only $E$. nilssonii was encountered in the standard $40-\mathrm{km}$ transect, yielding a relative density of 0.150 individuals per $\mathrm{km}$ of transect. The species has been repeatedly encountered in winter roosts outside living buildings in the village Kuganavolok and at the Vama post. Noteworthy are the unusually frequent encounters of Plecotus auritus in a stretch of the road Kuganavolok - River Navdruchey. Possibly, this area offers $P$. auritus the best conditions for daytime roosting and nighttime activity.

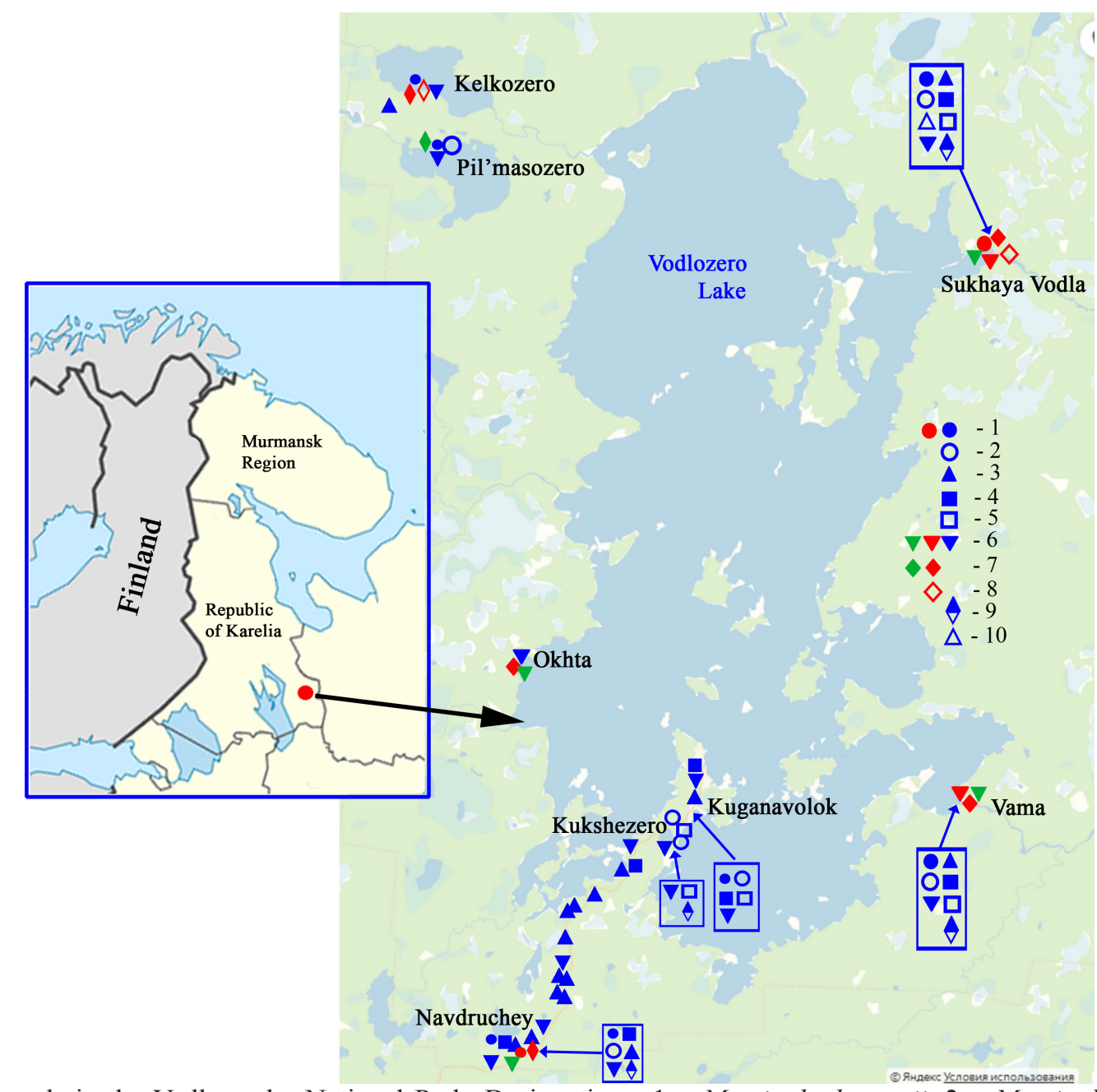

Fig. 5. Bat records in the Vodlozersky National Park. Designations: 1 - Myotis daubentonii, 2 - Myotis dasycneme, 3 Plecotus auritus, 4 - Nyctalus noctula, 5 - Vespertilio murinus, 6 - Eptesicus nilssonii, 7 - Myotis brandtii, 8 - Myotis mystacinus, 9 - Myotis brandtii/mystacinus, 10 - Myotis nattereri (green symbols - visual observations and sampling of biomaterial, red - mist-netting, blue - ultrasound detections). 
Table 4. Relative abundance (\%) of bats in the Vodlozersky National Park

\begin{tabular}{|l|c|c|c|c|}
\hline \multirow{2}{*}{\multicolumn{1}{c|}{ Species }} & \multirow{2}{*}{ Mist-netting } & \multicolumn{3}{c|}{ Ultrasound detection } \\
\cline { 3 - 5 } & & $\begin{array}{c}\text { At fixed } \\
\text { points }\end{array}$ & $\begin{array}{c}\text { Along car } \\
\text { transects }\end{array}$ & Total \\
\hline Myotis nattereri & - & 2.6 & - & 1.3 \\
\hline Myotis mystacinus & 10.7 & - & - & - \\
\hline Myotis brandtii & 46.4 & - & - & - \\
\hline Myotis brandtii/mystacinus & - & 10.3 & - & 5.1 \\
\hline Myotis daubentonii & 7.2 & 18.9 & - & 9.0 \\
\hline Myotis dasycneme & - & 15.3 & 7.7 & 11.5 \\
\hline Plecotus auritus & - & 10.3 & 38.4 & 24.4 \\
\hline Nyctalus noctula & - & 10.3 & 7.7 & 9.0 \\
\hline Eptesicus nilssonii & 35.7 & 23.0 & 43.6 & 33.3 \\
\hline Vespertilio murinus & - & 10.3 & 2.6 & 6.4 \\
\hline
\end{tabular}

At some points in the surveys, the results of mist-netting and ultrasound detection of bats suggest that the Sukhaya Vodla post had a colony of Eptesicus nilssonii, while the Vama post had a colony of Myotis brandtii. Summer findings of Myotis mystacinus at the Sukhaya Vodla post and Lake Kelkozero $\left(62.224867^{\circ} \mathrm{N}, 37.081629^{\circ} \mathrm{E}\right.$ and $\left.62.466342^{\circ} \mathrm{N}, 36.673240^{\circ} \mathrm{E}\right)$ are the northernmost records in European Russia.

In 2017, bat censuses by ultrasound detection in Kenozersky NP revealed five bat species (Myotis daubentonii, M. dasycneme, Plecotus auritus, Nyctalus noctula, and Eptesicus nilssonii) along car transects and water transects, as well as at fixed points. Besides, Vespertilio murinus was recorded from the village Afanasovskaya (30 km east of the Kenozersky NP border). The prevalent species in the Kenozersky NP was E. nilssonii; its relative abundance was $56 \%$, while other species contributed $4 \%$ to $16 \%$ (Table 2). Surveys of four standard $40-\mathrm{km}$ transects showed the overall relative density of bats in Kenozersky NP to be 0.115 individuals per $\mathrm{km}$ of transect, and like in the majority of other PAs, E. nilssonii was the dominant species (Table 5).
The above mentioned results demonstrated that Eptesicus nilssonii dominates in bat communities in the middle and northern taiga. The calculated relative densities of E. nilssonii in Karelia along the north-to-south gradient reached a maximum of 0.708 individuals per $\mathrm{km}$ of transect at $64-65^{\circ} \mathrm{N}$. The values of this parameter decline both to the south and to the north of this belt, with a minimum of 0.125 individuals per $\mathrm{km}$ above $66^{\circ} \mathrm{N}$. Eptesicus nilssonii encounters can be expected to get rarer and more fragmentary from the Arctic Circle to the northern limit of the forest zone, as it is observed in Finland (Mitchell-Jones et al., 1999; Tidenberg et al., 2019), in correlation with forest vegetation characteristics, altitudinal gradient, minimum air temperatures during breeding and hibernation (Michaelsen, 2016). As it was demonstrated by long-term observations in a place in Sweden, the decline in number of $E$. nilssonii was not only latitudinally, but also over time (Rydell et al., 2020). On the other hand, this species benefits from some ecological (hibernating in underground spaces of varying structure and microclimate, open or single localisation inside the hibernacula, later occupation of hibernacula in autumn and earlier emergence from hibernation compared to other species), physiological and biochemical advantages. They enable it to dominate in the northern and middle taiga subzones in terms of relative densities and relative abundances in winter and summer, as well as prevalence in human settlements and at water bodies in summer and in underground hibernacula in winter (Belkin et al., 2019a,b,c). Eptesicus nilssonii demonstrated a high ecological valence, including tolerance of extremely low temperatures at hibernacula (Fig. 6). Our studies showed E. nilssonii to be more tolerant than other species towards temperature, but not towards air humidity. As a result, E. nilssonii can live and breed up to a latitude of $70^{\circ} \mathrm{N}$ (Rydell et al., 1994).

Table 5. Relative density (individuals per km of transect) and locations of bats in Kenozersky National Park

\begin{tabular}{|l|c|l|}
\hline \multicolumn{1}{|c|}{ Species } & Relative density & \multicolumn{1}{c|}{ Locations } \\
\hline Myotis daubentonii & - & Lakes Lekshmozero, Kenozero, Svinoye \\
\hline Myotis dasycneme & 0.005 & Lake Svinoye \\
\hline Plecotus auritus & 0.010 & $\begin{array}{l}\text { Gory village, Sudorskaya Lahta Bay of Lake Kenozero, forest road to the } \\
\text { north of Lake Kenozero }\end{array}$ \\
\hline Nyctalus noctula & 0.025 & $\begin{array}{l}\text { Morshchihinskaya and Vershinino villages, watershed, Sudorskaya Lahta } \\
\text { Bay of Lake Kenozero }\end{array}$ \\
\hline Eptesicus nilssonii & 0.075 & $\begin{array}{l}\text { Villages (Morshchihinskaya, Orlovo, Maselga, Vershinino, Pershlahta, } \\
\text { Filippovskaya, Ust-Pocha), rivers (Sondola, Khabyanzya), Sudorskaya } \\
\text { Lahta Bay of Lake Kenozero }\end{array}$ \\
\hline
\end{tabular}




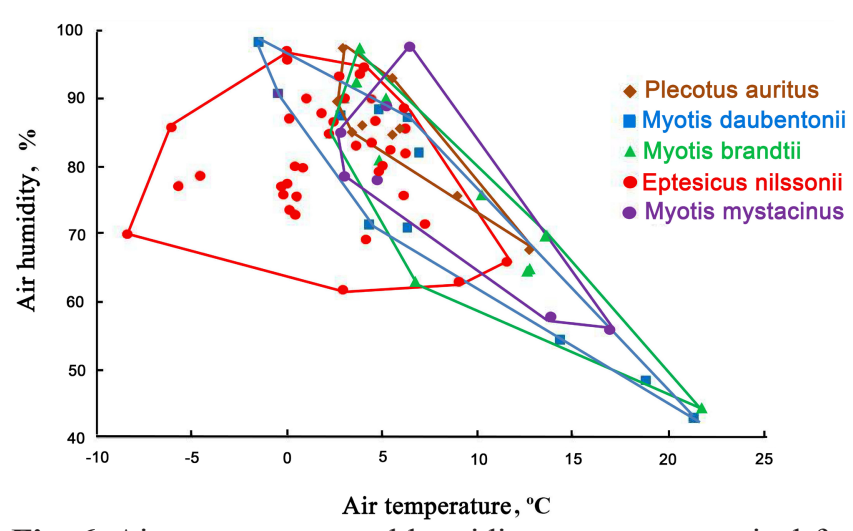

Fig. 6. Air temperature and humidity parameters typical for different bat species in underground hibernacula in the northern and middle taiga subzones. Each point represents the air temperature and humidity at the position where the bat individuals were found in underground hibernacula.

In general, PAs have an important role in the conservation of bat habitats in regions with extensive logging. They act as refugia where human pressure on chiropterans is minimised. Another specific characteristic of forest in PAs is the ample presence of dead standing trees. The availability of such trees, which usually have hollows and loose bark on trunks, can be an important factor for forest-dwelling bat species choosing daytime roosts and locations for the colony in summer (Ilyin et al., 2003; Dietz \& Kiefer, 2016), and for hibernation in winter. Thus, according to archival data from the Kalevalsky NP, where old-growth pine (Pinus sylvestris L.) forests prevail, there were 800-2000 hollowed trees per $\mathrm{km}^{2}$. In the Vodlozersky NP, where primary spruce (Picea abies (L.) Karst.) forests occupy $50.2 \%$ of the Vodlozersky NP's forest-covered area and the contribution of Pinus sylvestris L., Betula sp. and Populus tremula L. is substantial (up to $30 \%$ ), there were 2600 7600 dead standing trees per $\mathrm{km}^{2}$ (Ananev et al., 2001). Middle taiga pine forests aged 120-140 years contain 16000 dead standing trunks per $\mathrm{km}^{2}$ (Moshnikov et al., 2019). Their average diameter is $24 \mathrm{~cm}$. Our own previous counts of $P$. tremula thicker than $20 \mathrm{~cm}$ in diameter, in which hollows occur the most frequently, showed that the number of such trees in various forest types in the middle taiga subzone varied at 200-2200 trees per $1 \mathrm{~km}^{2}$ (Belkin et al., 2012). In native spruce stands, thick $P$. tremula are usually distributed more or less evenly, growing in small groups (2-4 trees). In mature secondary spruce stands, $P$. tremula usually grow in groups of 5-10 trees or in patches occupying up to 0.005 $\mathrm{km}^{2}$ (Volkov, 2008). Much attention is given to retention of dead standing and hollow-bearing trees in restricted areas during forest management and mitigation of forestry impact on bats (Law et al., 2016), irrespective of the forest type or geographical region.

In the conservation of bats, a special role belongs to Red Data Books, which urge specialists and the general public to focus more specifically on the most threatened species. Yet, the species checklists in some regional Red Data Books (Table 6) need to be revised, since they have grown outdated and new lists are being prepared in the meantime. For instance, in the Republic of Karelia, the revision will be done in 2020, supposedly leaving only two species on the Red Data Book list (Myotis mystacinus and Plecotus auritus), who live at the northern limit of their distribution ranges and have the lowest relative abundances at hibernacula (Belkin et al., 2018). The Red Data Book of the Murmansk region will retain $E$. nilssonii. The plan for the Red Data Book of the Arkhangelsk region is to keep Myotis dasycneme, M. brandtii, Plecotus auritus as the least studied species. In the southern taiga subzone, such revisions have already been made in the Leningrad region and are upcoming in the Vologda region.

Table 6. The bat species of the regional Red Data Books in the taiga zone of European Russia

\begin{tabular}{|c|c|c|c|c|c|c|c|c|c|c|c|}
\hline Region & 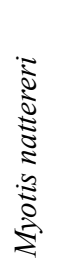 & 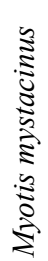 & 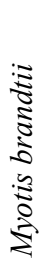 & 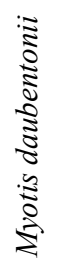 & 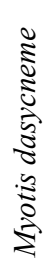 & 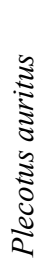 & 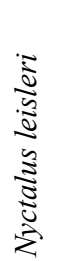 & 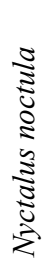 & 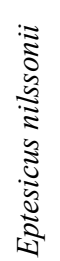 & 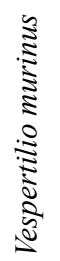 & Authors \\
\hline Murmansk region & - & - & - & - & - & - & - & - & + & - & Boiko, 2014 \\
\hline Republic of Karelia & - & + & - & + & + & + & - & - & - & - & Korosov, 2007 \\
\hline Arkhangelsk region & - & - & + & - & - & + & - & - & - & - & Rykov, 2008 b \\
\hline Leningrad region & + & + & + & - & + & - & - & - & - & - & Chistyakov, 2018 \\
\hline Vologda region & - & + & - & + & + & + & + & + & - & + & Konovalov, 2010 \\
\hline
\end{tabular}




\section{Conclusions}

Data reported above demonstrated that in PAs of the forest zone in European Russia, the bat populations are diverse. Their species richness increases in southward direction. Eptesicus nilssonii dominates in bat communities in the northern and middle taiga subzones. By the northern limit of its geographical range it turns into the only representative of the bat fauna. On the other hand, E. nilssonii is absent from more southern parts of the forest zone, or its relative abundance there is minimal, while the dominant faunal elements are Myotis daubentonii (Darwin SNR), N. noctula (Smolenskoye Poozerye NP, Oksky SNR and Bryansky Les SNR) and Pipistrellus nathusii (Prioksko-Terrasny SNR).

In contrary to our previous assumptions, Nyctalus noctula and Vespertilio murinus have been regularly recorded by ultrasound detection in both northern and middle taiga, which is a new finding. Their northernmost records alongside Plecotus auritus and Eptesicus nilssonii come from $66.343243^{\circ} \mathrm{N}, 30.343737^{\circ} \mathrm{E}$, and alongside Myotis dasycneme from $65.029154^{\circ} \mathrm{N}$, $30.364445^{\circ}$ E. Vodlozersky NP yielded the northernmost records of Myotis mystacinus in European Russia $\left(62.224867^{\circ} \mathrm{N}, 37.081629^{\circ} \mathrm{E}\right.$ and $62.466342^{\circ} \mathrm{N}, 36.673240^{\circ} \mathrm{E}$ ), and its coencounters together with Myotis brandtii, i.e. at hibernacula, suggest these species are sympatric, like they are in other parts of the species ranges. In general, PAs act as key refugia with minimal human pressure on bats, enhancing the overall well-being of chiropteran communities throughout the forest zone of European Russia.

\section{Acknowledgements}

The authors are grateful to E.A. Khizhkin and A.N. Lyapunov, as well as to the staff of the Protected Areas Yu.A. Krasovsky (Kostomuksha State Nature Reserve), E.V. Kholodov, E.N. Kholodova, V.N. Mamontov (Vodlozersky National Park), and S.I. Drovnina (Kenozersky National Park) for helping with the research. The study was carried out under state orders №0218-2019-0080 and №0218-2019-0073, RAS Presidium Programme №41 (project №0221-2018-0002), and with financial support from Kostomuksha State Nature Reserve, Vodlozersky National Park, and Kenozersky National Park.

\section{References}

Ahlén I., Baagøe H.J., Bach L. 2009. Behavior of Scandinavian bats during migration and foraging at sea. Journal of Mammalogy 90(6): 1318-1323. DOI: 10.1644/09-MAMM-S-223R.1
Ahlén I., Bach L., Baagøe H.J., Pettersson J. 2007. Bats and offshore wind turbines studied in Southern Scandinavia. Report 5571. Stockholm: Swedish EPA. 36 p.

Albov S.A., Kruskop S.V., Rosina V.V. 2009. The bats (Chiroptera) of Prioksko-Terrasny Reserve - thirty years of later. Plecotus et al. 13-12: 24-31. [In Russian]

Ananev V.A., Raevsky B.V., Grabovik S.I. 2001. Organization of forest monitoring in the primeval spruce forests of the national park «Vodlozersky». In: Vodlozersky National Park: natural diversity and cultural heritage. Petrozavodsk: Karelian Scientific Center of RAS. P. 118-122. [In Russian]

Ancillotto L., Santini L., Ranc N., Maiorano L., Russo D. 2016. Extraordinary range expansion in a common bat: the potential roles of climate change and urbanisation. The Science of Nature. 103(3-4): 15. DOI: 10.1007/s00114-016-1334-7

Anufriev A.I. 2008. Wintering and winter sleep of bats in Yakutia. Vestnik of North-Eastern Federal University 5(2): 5-9. [In Russian]

Artaev O.N., Smirnov D.G. 2016. The bats (Chiroptera; Mammalia) of Mordovia: specific structure and features of distribution. Nature Conservation Research 1(1): 38-51. DOI: 10.24189/ncr.2016.004

Baagøe H.J. 1973. Taxonomy of two sibling species of bats in Scandinavia Myotis mystacinus and Myotis brandtii (Chiroptera). Videnskabelige Meddelelser Dansk Naturhistorisk Forening 136: 191-216.

Barlow K.E., Jones G. 1999. Roosts, echolocation calls and wing morphology of two phonic types of Pipistrellus pipistrellus. Zeitschrift für Säugetierkunde 64: 257-268.

Belkin V.V., Ilyukha V.A., Khizhkin E.A., Fyodorov F.V., Morozov A.V., Yakimova A.E. 2018. Species composition and distribution of Chiroptera (Vespertilionidae) in Karelia. Principles of the Ecology 7(3): 13-23. DOI: 10.15393/j1.art.2018.8042 [In Russian]

Belkin V.V., Khizhkin E.A., Yakimova A.E., Antonova E.P., Fyodorov F.V., Kizhina A.G., Uzenbayeva L.B., Ilyina T.N., Baishnikova I.V., Ilyukha V.A. 2019a. Ecological and physiological-biochemical preferences of the northern bat (Eptesicus nilssonii L.) as a factor of species dominance at northern latitudes. In: Ecological problems of the northern regions and ways to solve them. Apatity. P. 204-206. [In Russian]

Belkin V.V., Ilyukha V.A., Khizhkin E.A., Fyodorov F.V., Yakimova A.E. 2019b. Studies of the bat fauna (Mammalia, Chiroptera) in the Green Belt of Fennoscandia. Transactions of the Karelian Research Centre of the Russian Academy of Sciences 5: 17-29. DOI: 10.17076/eco1079 [In Russian]

Belkin V.V., Ilyukha V.A., Khizhkin E.A., Fyodorov F.V., Yakimova A.E. 2019c. Underground fortifications in the subzones of the middle and northern taiga as a wintering place for bats. In: Speleology and spelestology. Vol. 10. Naberezhnye Chelny. P. 279-284. [In Russian]

Belkin V.V., Tirronen K.F., Panchenko D.V. 2012. Flying squirrel (Pteromys volans L.) in taiga forests of the 
European North. Problems of Regional Ecology 1: 101-105. [In Russian]

Bogdarina S.V. 2004. Notes about bats (Chiroptera, Vespertilionidae) on the island of Valaam. Plecotus et al. 7: 18-21. [In Russian]

Bogdarina S.V., Strelkov P.P. 2003. Distribution of bats (Chiroptera) in the north of European Russia. Plecotus et al. 6: 7-28. [In Russian]

Boiko N.S. 2014. The Northern bat. In: Red Data Book of the Murmansk region. Kemerovo: Asia-print. P. 559-560. [In Russian]

Bolshakov V.N., Orlov O.L., Snitko V.P. 2005. Bats of the Urals. Yekaterinburg: Akademkniga. 176 p. [In Russian]

Chistyakov D.V. 2018. Bats - Chiroptera. In: Red Data Book of the Leningrad region: Animals. Saint-Petersburg. P. 475-479. [In Russian]

Dietz C., Helversen von O., Nill D. 2011. Bats of Britain, Europe and Northwest Africa. London: A\&C Black. 400 p.

Dietz C., Kiefer A. 2016. Bats of Britain and Europe. UK: Bloomsbury Publishing. 400 p.

Hamphries M.M., Thomas D.W., Speakman J.R. 2002. Climate-mediated energetic constraints on the distribution of hibernating mammals. Nature 418: 313316. DOI: $10.1038 /$ nature 00828

Hanák V. 1970. Notes on the distribution and systematics of Myotis mystacinus Kuhl, 1819. Bijdragen tot de Dierkunde 40(1): 40-44. DOI: 10.1163/26660644-04001012

Ilyin V.Yu., Smirnov D.G., Yanyaeva N.M. 2003. Effects of the Anthropogenic Factor on Bats (Chiroptera: Vespertilionidae) in the Volga Region. Russian Journal of Ecology 34(2): 122-126. DOI: 10.1023/A:1023003215329

Jones K.E., Russ J.A., Bashta A.T., Bilhari Z., Catto C., Csősz I., Gorbachev A., Győrfi P., Hughes A., Ivashkiv I., Koryagina N., Kurali A., Langton S.D., Collen A., Mărginean G., Pandourski I., Parsons S., Prokofev I., Szodoray-Parádi A., Szodoray-Parádi F., Tilova E., Walters C.L., Weatherill A., Zavarzin O. 2013. Indicator bats program: a system for the global acoustic monitoring of bats. In: Collen B., Pettorelli N., Baillie J.E.M., Durant S.M. (Eds.): Biodiversity Monitoring and Conservation: Bridging the Gap between Global Commitment and Local Action. John Wiley-Blackwell. P. 213-247. DOI: 10.1002/9781118490747.ch10

Kataev G.D. 2018. Annotated list of mammal species. In: Vertebrates of the Pasvik State Nature Reserve. Petrozavodsk. P. 193-207. [In Russian]

Konovalov A.F. 2010. Bats - Chiroptera. In: Red Data Book of the Vologda Region. Vol. 3: Animals. Vologda: Poligraf-Kniga. P. 184-185. [In Russian]

Korosov A.V. 2007. Order of bats (Chiroptera). In: Red Data Book of the Republic of Karelia. Petrozavodsk. P. 169-171. [In Russian]

Kravchenko A.V., Lazareva I.P. 1989. Natural conditions. In: Valaam ecosystems and their protection. Petrozavodsk. P. 6-14. [In Russian]

Kruskop S.V. 2007. On distribution of pipistrelles from Pipistrellus pipistrellus/pygmaeus complex (Chirop- tera, Vespertilionidae) in Russia. Plecotus et al. 10: 36-46. [In Russian]

Law B., Park K.J., Lacki M.J. 2016. Insectivorous bats and silviculture: balancing timber production and conservation. In: Bats in the Anthropocene: Conservation of Bats in a Changing World. Springer, Cham. P. 105-150. DOI: 10.1007/978-3-319-25220-9_5

Lehmann R. 1983-1984. Myotis mystacinus (Kuhl, 1819) and Myotis brandtii (Eversmann, 1845) in Finland. Myotis 21-22: 96-101.

Lehnert L.S., Kramer-Schadt S., Schönborn S., Lindecke O., Niermann I., Voigt C.C. 2014. Wind farm facilities in Germany kill noctule bats from near and far. PLoS ONE 9(8): e103106. DOI: 10.1371/journal. pone. 0103106

Mamontov V.N. 2006. Mammals. In: Nature and historical and cultural heritage of Kozhozerye. Arkhangelsk. P. 233-243. [In Russian]

Michaelsen T.C. 2016. Summer temperature and precipitation govern bat diversity at northern latitudes in Norway. Mammalia 80(1): 1-9. DOI: 10.1515/mammalian-2014-0077

Michaelsen T.C., Jensen K.H., Högstedt G. 2011. Topography is a limiting distributional factor in the soprano pipistrelle at its latitudinal extreme. Mammalian Biology 76(3): 295-301. DOI: 10.1016/j. mambio.2010.12.004

Miller B.W. 2001. A method for determining relative activity of free flying bats using a new activity index for acoustic monitoring. Acta Chiropterology 3(1): 93-106.

Mitchell-Jones A.J., Amori G., Bogdanowicz W., Krystufek B., Reijnders P.J., Spitzenberger F., Stubbe M., Thissen J.B., Vohralik V., Zima J. 1999. The Atlas of European Mammals. London: T\&A. D. Poyser. 484 p.

Moshnikov S.A., Ananev V.A., Matyushkin V.A. 2019. Storages of Coarse Woody Debris in Pine Forests of Middle Taiga of Northwestern Russia (Case Study in Karelia). Russian Journal of Forest Science 4: 266 273. DOI: 10.1134/S0024114819040041 [In Russian]

Pereswiet-Soltan A. 2007. Relation between climate and bat fauna in Europe. Travaux du Museum National d'Histoire Naturelle «Grigore Antipa» 50: 505-515.

Poerink B.J., Lagerveld S., Verdaat H. 2013. Pilot study. Bat activity in the Dutch offshore wind farms Owex and Pawp. Groningen: The Fieldwork Company. 19 p.

Rebelo H., Tarroso P., Jones G. 2010. Predicted impact of climate change on European bats in relation to their biogeographic patterns. Global Change Biology 16(2): 561-576. DOI: 10.1111/j.13652486.2009.02021.x

Russ J.M., Briffa M., Montgomery W.I. 2003. Seasonal patterns in activity and habitat use by bats (Pipistrellus spp. and Nyctalus leisleri) in Northern Ireland, determined using a driven transect. Journal of Zoology 259(3): 289-299. DOI: 10.1017/ S0952836902003254

Russo D., Voigt C.C. 2016. The use of automated identification of bat echolocation calls in acoustic monitoring: A cautionary note for a sound analysis. 
Ecological Indicators 66: 598-602. DOI: 10.1016/j. ecolind.2016.02.036

Rydell J., Bach L., Bach P., Diaz L.G., Furmankiewicz J., Hagner-Wahlsten N., Kyherцinen E.M., Lilley T., Masing M., Meyer M., Pstersons G., Puba J., Vasko V., Vintulis V., Hedenstrцm A. 2014. Phenology of migratory bat activity across the Baltic Sea and the south-eastern North Sea. Acta Chiropterologica 16(1): 139-147. DOI: 10.3161/150811014X683354

Rydell J., Elfstrom M., Eklof J., Sanchez-Navarro S. 2020. Dramatic decline of northern bat Eptesicus nilssonii in Sweden over 30 years. Royal Society Open Science 7(2): 191754. DOI: 10.1098/rsos.191754

Rydell J., Nyman S., Eklцf J., Jones G., Russo D. 2017. Testing the performances of automated identification of bat echolocation calls: a request for prudence. Ecological Indicators 78: 416-420. DOI: 10.1016/j. ecolind.2017.03.023

Rydell J., Strann K.B., Speakman J.R. 1994. First record of breeding bats above the Arctic Circle: northern bats at $68-70^{\circ} \mathrm{N}$ in Norway. Journal of Zoology 233(2): 335-339. DOI: 10.1111/j.1469-7998.1994.tb08597.x

Rykov A.M. 2008a. Bats. Components of Ecosystems and Biodiversity in Karst Territories of Northern European Russia: The Example of Pinega State Nature Reserve. Arkhangelsk. 293-294. [In Russian]

Rykov A.M. 2008b. Family of vesper bats - Vespertilionidae. In: Red Data Book of the Arkhangelsk Region. Arkhangelsk. P. 298-300. [In Russian]

Semenov-Tjan-Shanskii O.I. 1982. Mammals of the Murmansk region. Murmansk: Murmansk Book Publishing House. 175 p. [In Russian]

Shpak A.V. 2019. Protection and principles of the study of bats in Protected Areas. In: Current Status and Prospects for the Development of Protected Areas (PAs). Minsk. P. 99-103. [In Russian]

Shpilenok I.P., Korshunova E.N., Tarasov A.G. 1997. Rare and threatened mammal species of NerussoDesnyansky district. In: Rare and Threatened Plant and Animal Species Nerusso-Desnyansky Physiographic Region. Bryansk: Grany Press. P. 242-249. [In Russian]

Shutova E.V. 2016. The impact of climate warming on the spread of some insect species to the north. In: Proceedings of the All-Russian Scientific and Practical Conference with international participation dedicated to the $25^{\text {th }}$ anniversary of the UNESCO Biosphere Reserve «Vodlozersky National Park». Petrozavodsk. P. 265-266. [In Russian]

Siivonen Y., Wermundsen T. 2008. Characteristics of winter roosts of bat species in southern Finland. Mammalia 72(1): 50-56. DOI: 10.1515/MAMM.2008.003

Sitnikova E.F., Kruskop S.V., Mishta A.V. 2009. Materials on the bat fauna of Bryansk region. Plecotus et al. 11-12: 32-49. [In Russian]

Skorokhodova S.B., Shcherbakov A.N. 2011. Trends in the onset of phenological events in the Kivach State Nature Reserve in 1966-2005. Proceedings of the Kivach State Nature Reserve 5: 207-221. [In Russian]
Snitko V.P. 2000. Proposed activities for the monitoring of bats in protected areas of the Urals. In: Coordination of environmental monitoring in the protected areas of the Urals. Ekaterinburg. P. 239. [In Russian]

Starikov D.A., Popov I.Yu. 2012. Bats in the territory of the Nizhne-Svirsky State Nature Reserve. Proceedings of the Nizhne-Svirsky State Nature Reserve 2: 1-168. [In Russian]

Strelkov P.P. 1997a. Breeding area and its position in range of migratory bats species (Chiroptera, Vespertilionidae) in East Europe and adjacent territories - Communication 1. Zoologicheskii Zhurnal 76(9): 1073-1082. [In Russian]

Strelkov P.P. 1997b. Breeding area and its position in range of migratory bats species (Chiroptera, Vespertilionidae) in east Europe and adjacent territories: Communication 2. Zoologicheskii Zhurnal 76(12): 1381-1390. [In Russian]

Strelkov P.P. 2004. Expansion of habitats by Palearctic bats (Chiroptera, Mammalia) as an example of invasion in anthropogenic biotopes. In: Biological invasions in aquatic and terrestrial ecosystems. Moscow, Saint Petersburg. P. 202-207. [In Russian]

Strelkov P.P., Buntova E.G. 1982. Myotis mystacinus and Myotis brandtii (Chiroptera, Vespertilionidae) and interrelations of these species. Part 1. Zoologicheskii Zhurnal 61(8): 1227-1241. [In Russian]

Strelkov P.P., Ilyin V.Yu. 1990. The bats (Chiroptera, Vespertilionidae) of the south Middle Volga and Lower Volga provinces. Proceedings of the Zoological Institute of the Academy of Sciences of the USSR 225: 42-167. [In Russian]

Tidenberg E.M., Liukko U.M., Stjernber T. 2019. Atlas of Finnish bats. Annales Zoologici Fennici 56(1-6): 207-250. DOI: 10.5735/086.056.0117

Ulrich W., Sachanowicz K., Michalak M. 2007. Environmental correlates of species richness of European bats (Mammalia: Chiroptera). Acta Chiropterologica 9(2): 347-360. DOI: 10.3161/1733-5329(2007)9[347:EC OSRO]2.0.CO;2

Vasenkov D.A., Sidorchuk N.V. 2010. Dynamics of bat species composition by the results of mist-netting in summer period in the Darwin State Nature Reserve. Plecotus et al. 13: 32-33. [In Russian]

Vasenkov D.A., Sidorchuk N.V., Khokhryakov V.R. 2017. «Sedentary» and «migrating» population of bats in the Smolenskoye Poozerye National Park. Plecotus et al. 20: 54-67.

Vekhnik V.P., Sachkov S.A. 2005. Proposals for the programme on eco-faunal monitoring of bats in Protected Areas. Plecotus et al. 8: 77-80. [In Russian]

Verzilin A.V., Kondrashova K.V., Troshchii A.I. 1990. Some biological features of apple trees in the gardens of Valaam. In: Planting of trees and gardens in Karelia. Petrozavodsk: KarRC AS USSR. P. 97-103. [In Russian]

Vlaschenko A., Kravchenko K., Prylutska A., Ivancheva E., Sitnikova E., Mishin A. 2016. Structure of summer bat assemblages in forests in European Rus- 
sia. Turkish Journal of Zoology 40: 867-893. DOI: 10.3906/zoo-1508-56

Voigt C.C., Lindecke O., Schönborn S., Kramer-Schadt S., Lehmann D. 2016. Habitat use of migratory bats killed during autumn at wind turbines. Ecological Applications 26(3): 771-783. DOI: 10.1890/15-0671

Volkov A.D. 2008. Forest types of Karelia. Petrozavodsk: KarRC of RAS. 180 p. [In Russian]
Zaugolnova L.B., Martynenko V.B. 2014. Colour map of the European part of Russia. In: Key to forest types of European Russia. Available from http://www.cepl. rssi.ru/bio/forest/karta 1.htm [In Russian]

Zimin V.B., Ivanter E.V. 1969. Faunistic survey of terrestrial vertebrates of the Kivach State Nature Reserve. Proceedings of the Kivach State Nature Reserve 1: 22-64. [In Russian]

\title{
ОСОБЕННОСТИ НАСЕЛЕНИЯ ЛЕТУЧИХ МЫШЕЙ (СНIROРТЕRА) НА ОСОБО ОХРАНЯЕМЫХ ПРИРОДНЫХ ТЕРРИТОРИЯХ В ПОДЗОНАХ СЕВЕРНОЙ И СРЕДНЕЙ ТАЙГИ ЕВРОПЕЙСКОЙ РОССИИ
}

\author{
В. В. Белкин $\mathbb{D}$, Ф. В. Федоров* ${ }^{\mathbb{D}}$, В. А. Илюха $\mathbb{D}$, А. Е. Якимова $\mathbb{D}$ \\ Институт биологии Карельского научного иеентра РАН, Россия \\ *e-mail:ffyodoroff@inbox.ru
}

Фауна летучих мышей (Chiroptera) особо охраняемых природных территорий (ООПТ) лесной зоны Европейской России в целом не оценивалась, хотя работы по отдельным ООПТ выходят достаточно регулярно. Вдоль широтного градиента эта обширная территория охватывает самые различные места обитания рукокрылых, пригодные для принципиально разнообразного состава населения летучих мышей. Для обзора видов летучих мышей мы сфокусировались на восьми ООПТ подзон северной и средней тайги, а также на кратком сравнительном обзоре фаунистической литературы в целом по лесной зоне Европейской России. По результатам учетов с использованием Ват-детектора и паутинных сетей, выявлены видовой состав, относительное обилие, относительная численность и распределение рукокрылых на ООПТ. Зарегистрировано девять видов летучих мышей: Myotis nattereri, M. mystacinus, M. brandtii, M. daubentonii, M. dasycneme, Plecotus auritus, Nyctalus noctula, Eptesicus nilssonii, Vespertilio murinus. Показана регулярная регистрация ультразвуковых сигналов Plecotus auritus, Nyctalus noctula и Vespertilio murinus до $66^{\circ} \mathrm{N}$, что значительно севернее видовых ареалов, показанных на картах МCOП (IUCN Red List). При отсутствии специальных учетов в Карелии и Архангельской области на протяжении десятилетий этот результат стал неожиданным. Выявлено доминирование Eptesicus nilssonii в сообществах рукокрылых на ООПТ, что характерно только для подзон северной и средней тайги. Обсуждаются некоторые экологические предпочтения этого вида, такие как большая толерантность E. nilssonii по сравнению с другими видами в отношении температуры, но не влажности воздуха в зимних убежищах, позволяющие ему осваивать высокие широты. В то же время, в более южных частях лесной зоны E. nilssonii отсутствует или его относительное обилие минимально, а доминирующими видами выступают Myotis daubentonii (Дарвинский заповедник), Nyctalus noctula (национальный парк «Смоленское поозерье», Окский заповедник и заповедник «Брянский лес») и Pipistrellus nathusii (Приокско-Террасный заповедник). Результаты отлова рукокрылых паутинными сетями в национальном парке «Водлозерский» выявили самые северные точки встреч Myotis mystacinus на севере Европейской России $\left(62.224867^{\circ} \mathrm{N}, 37.081629^{\circ} \mathrm{E}\right.$ и $62.466342^{\circ} \mathrm{N}$, $36.673240^{\circ}$ E). В заключении, на основании последних учетов летучих мышей, мы обсуждаем необходимость пересмотра статуса рукокрылых в региональных Красных книгах.

Ключевые слова: видовой состав, Красная книга, относительное обилие, относительная численность, распространение 